\title{
Y Kuşağı Bireylerin Sağlıklı Yaşam Farkındalık Düzeylerinin İncelenmesi
}

\author{
Investigation of Generation Y Individuals for Healthy Life Awareness Levels
}

\author{
Necla YILMAZ ${ }^{1}$, Elif ÖZER ${ }^{2}$
}

\section{ÖZ}

Bu çalışmada Isparta il merkezinde ikamet eden $\mathrm{Y}$ kuşağı bireylerin sağlıklı yaşam farkındalık düzeylerinin çeşitli değişkenler açısından incelenmesi amaçlanmıştır. Araştırmaya kolayda örnekleme yöntemiyle Isparta ilinde ikamet eden 21-40 yaş aralığında 382 birey dahil edilmiştir. Katılımcılara sosyo-demografik özellikler ile Sağlıklı Yaşam Farkındalığı Ölçeği'ni (SYFÖ) içeren anket formu uygulanmıştır. Araştırmanın verileri t testi, ANOVA (F testi) ve Korelasyon analizi ile elde edilmiştir. Sağlıklı yaşam farkındalığı alt boyutları arasında en yüksek ortalamayı değişim $(4,147 \pm 0,661)$ boyutunun ve en düşük ortalamayı ise, sosyalleşme $(3,327 \pm 0,937)$ boyutunun aldığı görülmüştür. Yapılan korelasyon analizi sonucunda sağlıklı yaşam farkındalığ 1 alt boyutları arasında anlamlı pozitif ilişkiler bulunmuştur. Gruplar arasında yaş, medeni durum, eğitim, sigara içme ve kronik hastalık değişkenlerinde anlamlı bir farklılık tespit edilmiştir. Bireylerin sağlıklı yaşama dair farkındalık düzeylerinin orta düzeyin üzerinde olduğu belirlenmiştir.

Anahtar Kelimeler: Farkındalık, Sağlıklı Yaşam, Y kuşağ 1

\begin{abstract}
In this study, it was aimed to examine the healthy life awareness levels of generation y individuals living in Isparta city center in terms of various variables. The study included 382 individuals between the ages of 20-40, residing in Isparta, using the convenience sampling method. A questionnaire including sociodemographic characteristics and the Healthy Life Awareness Scale (PIFS) was applied to the participants. The data of the study were obtained by $t$ test, ANOVA (F test) and Correlation analysis. Among the healthy life awareness sub-dimensions, it was observed that the change dimension was the highest $(4.147 \pm 0.661)$ and the socialization dimension $(3.327 \pm 0.937)$ was the lowest. As a result of the correlation analysis, significant positive relationships were found between health awareness sub-dimensions. A significant difference was found between the groups in age, marital status, education, smoking and chronic disease variables. It has been determined that individuals' awareness levels about healthy living are above the medium level.
\end{abstract}

Keywords: Awareness, Healthy Life, Generation Y

\footnotetext{
${ }^{1}$ Dr. Öğr. Üyesi, Necla YILMAZ, Sağlık Yönetimi, Süleyman Demirel Üniversitesi Sağlık Yönetimi Bölümü, neclabardak@sdu.edu.tr, ORCID: :0000-0002-9847-6888

${ }^{2}$ Doktora Öğrencisi, Elif ÖZER, Sağlık Yönetimi, Süleyman Demirel Üniversitesi Sosyal Bilimler Enstitüsü, elif.ozer94@hotmail.com ORCID: 0000-0002-3745-2399
} 


\section{GIIRIŞ}

Kuşak kavramı temel olarak yaş kavramına dayanmaktadır. Geleneksel olarak kuşak kavramı, ebeveynlerin doğumuyla çocuklarının doğumu arasındaki ortalama zaman aralığı olarak tanımlanmaktadır. ${ }^{1}$ Ancak kuşak kavramı sadece bir yaş ya da bir dönem olarak değerlendirilmemelidir. Alman bilim sosyoloğu Karl Mannheim The Problem of Generations adlı çalışmasında, bir kuşağın oluşumunda önceliğin aynı yaş grubuna ait olduğunu söylemektedir. Fakat bunun tek başına yeterli olmadığından, aynı yaş grubunda çoğu insanın ortak paylaştığ bazı sosyal ve kültürel faktörlerin olması gerektiğinden bahsetmektedir. $^{2}$ Özellikle kadınların iş hayatına atılması, kariyer algısı, geç evlenmeler ve geç doğumlar gibi bazı sosyo-kültürel değissimler sonucunda, yalnızca doğum esaslı yapılan biyolojik tanımların yanı sira sosyolojik tanımların da önemi ortaya çıkmıştır. Örneğin 1982 yılında ilk bebeğini dünyaya getiren bir kadının ortalama yaşı 25 kabul edilirken, 2010 yılında bu yaş 31 olmuştur. ${ }^{1} \mathrm{Bu}$ bağlamda kuşak kavramını; belirli zaman aralıklarında doğmuş, büyümüş ve yaşamını sürdürmüş, söz konusu dönemde yaşanan olaylardan etkilenmiş dolayısıyla ortak özelliklere ve bakış açılarına sahip oldukları varsayılan insan grupları olarak tanımlamak mümkündür. ${ }^{3} \mathrm{Bu}$ nedenle her kuşağın kendine özgü özellikleri, değer yargıları, tutumları, güçlü ve zayıf yönleri bulunmaktadır. ${ }^{4}$ Kuşaklar; sessiz kuşak, patlama kuşağı, X, Y ve $Z$ kuşağı şeklinde sinıflandırılmaktadır. ${ }^{5-6}$

Milenyum Kuşağı (Millennials), Gelecek Kuşak (Generation Next), Gen Y (Generation Y), Dijital Kuşak (Digital Generation) ve İnternet Kuşağ ${ }^{7}$ gibi isimlerle de anılan Y Kuşağı, 1980 ve 2000 yılları arasında doğan kişileri kapsamaktadır. ${ }^{8}$ Günümüzde dünya nüfusunun en kalabalık kuşağı olmasının yanı sıra yapılan kuşak çalışmalarında en çok dikkat çeken kuşak olarak öne çıkmaktadır. ${ }^{9}$ Y kuşağının karakteristik özelliklerine bakıldığında ilk dikkat çeken şey teknolojiye olan eğilimleridir. Diğer kuşaklara nazaran teknolojinin içinde doğan bu kuşak günlük işlerini ve sahip oldukları görevleri yerine getirmek için siklıkla teknolojiye başvurmaktadır. ${ }^{10}$ Aynı zamanda araştırma yapmayı seven ve meraklı yapıları ile $Y$ kuşağı, sahip oldukları teknoloji donanımı ile bilgi edinme süreçlerinde problem yaşamamakta ve edindikleri bilgileri doğru yerde ve doğru zamanda kullanmaktadırlar. ${ }^{11}$ Sosyal ilişkilerine de büyük önem veren $Y$ kuşağı, bu ilişkileri geliştirmek ve sosyalleşmek için vakit ayırmak istemektedirler. $^{12} \mathrm{Y}$ kuşağının diğer özelliklerine bakıldığında ise; hedef odaklı, bireysel, özgürlüğe önem veren, hızlı düşünüp hızlı karar alan, kendilerini seven, sorgulayıc1, öğrenmeye açık ve yüksek performansa sahip oldukları görülmektedir. ${ }^{13}$

Sağlık, insan yaşamının sürdürülmesinde, yaşam kalitesinin yükseltilmesinde ve korunmasında özel bir öneme sahiptir. Sağlığın korunması ve geliştirilmesi kişinin öncelikle kendi sağlı̆̆ına sahip çıkması ve sağlık bilincini geliştirmesi ile mümkündür. ${ }^{14}$ Toplumun sağlıklı olması da toplumu oluşturan bireylerin kendi sağ lığının farkında olması ve kendi sağlığını korumaya yönelik çaba göstermesine bağlıdır. ${ }^{15} \mathrm{Bu}$ bağlamda farkındalığın, bir canlının çevresinde gelişen olayları bilme, algilama ve duyumsama becerisi ile bireylere bir şeyi nasıl yaptıklarını açıklamaları ile ilgili olduğu söylenebilir. Farkındalık düzeyinin yüksek olması ise bireylere kendileri ve çevrelerini düzenleyebilmek için gerekli olan geri bildirimi sağlayarak, yaşamlarına yön vermeleri açısından önemli görülmektedir. Kişinin farkındalık düzeyindeki artış kendisine, çevresine ve evrene ilişkin bilinçlilik düzeyinde de artışa sebep olur. Genellikle "fark etme, bilinçlilik hali" şeklinde tanımlanmaktadır. ${ }^{16-17} \mathrm{Bu}$ kapsamda bu çalışma ile TÜİK 2019 verilerine göre Türkiye nüfusunda en fazla paya sahip olan Y kuşağı bireylerinin sağlıklı yaşam farkındalığı düzeylerinin ölçülmesi amaçlanmaktadır. 


\section{MATERYAL VE METOT}

\section{Araştırmanın Amacı}

$\mathrm{Bu}$ çalışma Isparta il merkezinde ikamet eden Y kuşağı bireylerin sağlıklı yaşam farkındalık düzeylerinin çeşitli değişkenler açısından incelenmesini amaçlamaktadır.

\section{Evren ve Örneklem}

Araştırmanın evrenini; 2019-2020 y1lı içerisinde, Isparta'da ikamet eden 21-40 yaş gurubu bireyler oluşturmaktadır. Araştırmanın verileri, kolayda örnekleme yöntemiyle $382 \mathrm{Y}$ kuşağı bireyinden yüz yüze anket tekniği kullanılarak elde edilmiştir. Araştırma, etik kurul izni alınd1ktan sonra 01.01.2020 ve 15.01.2020 tarihleri arasında yürütülmüştür.

\section{Veri Toplama Araci}

Araştırmada veri toplama aracı olarak Özer ve Yılmaz ${ }^{18}$ tarafından geliştirilmiş 15 ifadeli Sağlıklı Yaşam Farkındalığı ölçeği kullanılmıştır. Ölçeğin 4 alt boyutu vardır. Bunlar; "Değişim" (5 madde), "Sosyalleşme" (4 madde), "Beslenme" (3 madde) ve "Sorumluluk" (3 madde) şeklindedir. Ölçekte, (1) Kesinlikle katılmıyorum ve (5) Kesinlikle Katıliyorum şeklinde 5'li bir likert kullanılmıştır. Araştırmada ölçeğin güvenilirlik değeri 829 olarak hesaplanmıştır.

\section{Analiz Yöntemi}

Çalışmanın verileri bilgisayar ortamına aktarılmış, standart sapma, aritmetik ortalama, frekans ve yüzde hesaplamaları Statistical Package for the Social Sciences (SPSS 22.0) paket programı vasitasiyla analiz edilmiştir. Boyutların sosyodemografik değiş̧kenlere göre karşılaştırılmasında; ikili gruplarda $\mathrm{t}$ testi (independent $t$ test), üç ve daha fazla değişkenli gruplarda ise ANOVA ( $\mathrm{F}$ testi) kullanılmıştır. Varyans analizinde farklılığın hangi grup ya da gruplardan kaynaklandığının belirlenmesi amacıyla ise LSD testinden faydalanılmıştır. Ayrıca ankette yer alan bağımsız sorular ile ölçek boyutları arasındaki ilişkiyi tespit etmek amacıyla korelasyon analizi yapılmıştır.

\section{Araştırmanın Etik Yönü}

Çalışmanın yürütülebilmesi için Süleyman Demirel Üniversitesi Etik Kurulu (87432956/050.99/63750) tarafindan gerekli izin alınmış olup, katılımcılar, gönüllülük esasına dayalı olarak araştırmaya katılabilecekleri konusunda bilgilendirilmiştir.

\section{BULGULAR VE TARTIŞMA}

Tablo 1'de katılımcıların yaş gruplarına göre dağılımlarına bakıldığında \%31,9'unun 21-23, \%28,3'ünün 24-26 yaş aralığında, $\% 12,0$ 'sinin 27-29 yaş aralığında ve $\% 27,7$ 'sinin 30 ve üzeri yaşta olduğu görülmektedir. \%52,9'u kadınlardan oluşan katılımcıların, \%73,3'ünün evli olmadığ 1 , \% 55,0 'inin 3000 TL ve alt 1 gelire ve $\% 47,1$ 'inin lisans düzeyinde eğitime sahip olduğu görülmektedir. Katılımciların sigara kullanma durumlarına bakıldığında \%46,9'u sigara kullanan, \%53,1'i sigara kullanmayan bireylerden oluşmaktadır. \%51,6 gibi bir çoğunluğun günde 8 saat ve üzeri uyudukları görülmektedir. Katılımcıların \%42,4'ünün $1000 \mathrm{ml}$ ve altı, \%41,1'inin ise $1200 \mathrm{ml}-2000$ $\mathrm{ml}$ aralığında günlük su tükettiği görülmektedir. $\mathrm{Bu}$ dilimlerin birbirine çok yakın olduğu görülmektedir. Katılımcıların büyük çoğunluğunu oluşturan \%89,3'ünün kronik bir hastalığı bulunmamaktadır. Son 1 yılda hekime başvurma sayılarına bakıldığında ise katılımcıların \%22,0'sini 2 kez, \%18,8'ini başvuru yapmayan ve \%17,5'ini 3 kez başvuru yapan bireyler oluşturmaktadır. Katılımcıların \%63,1'i çevrelerinden psikolojik ve sosyal açıdan yeterli desteği aldıklarını ifade ederken $\% 35,9$ 'u yeterli desteği almadıklarını ifade etmiştir. Katılımcıların \%53,7'si fiziksel aktivite yaptığını belirtirken, en çok fiziksel aktivite türü olarak \%18,1'lik bir kısım yalnızca yürüyüş yaptığını belirtmiştir. 
Tablo 1. Katılımcıların Tanıtıcı Özellikleri

\begin{tabular}{|c|c|c|c|c|c|}
\hline Değişkenler & $\mathrm{n}$ & $\%$ & & $\mathrm{n}$ & $\%$ \\
\hline Yaş & & & \multicolumn{3}{|c|}{ Son 1 yılda hekime başvuru sayınız? } \\
\hline $21-23$ & 122 & 31,9 & $1 \mathrm{kez}$ & 47 & 12,3 \\
\hline $24-26$ & 108 & 28,3 & $2 \mathrm{kez}$ & 84 & 22,0 \\
\hline $27-29$ & 46 & 12,0 & $3 \mathrm{kez}$ & 67 & 17,5 \\
\hline $30 \leq$ & 106 & 27,7 & $4 \mathrm{kez}$ & 38 & 9,9 \\
\hline Cinsiyet & & & $5 \mathrm{kez}$ & 35 & 9,2 \\
\hline Kadın & 202 & 52,9 & $6 \leq$ & 39 & 10,2 \\
\hline Erkek & 180 & 47,1 & Başvurmayan & 72 & 18,8 \\
\hline $\begin{array}{l}\text { Medeni durum } \\
\text { musunuz? }\end{array}$ & & & Çevrenizden yeterli de & aldığınızı & düşünüyor \\
\hline Evli & 102 & 26,7 & Evet & 241 & 63,1 \\
\hline Evli değil & 280 & 73,3 & Hayır & 135 & 35,9 \\
\hline Aylık gelir & & & Belirtmeyen & 6 & 1,6 \\
\hline $3000 \geq$ & 210 & 55,0 & \multicolumn{3}{|c|}{ Fiziksel aktivite yapıyor musunuz? } \\
\hline $3001 \leq$ & 70 & 18,3 & Evet & 205 & 53,7 \\
\hline Belirtmeyen & 102 & 26,7 & Hayır & 177 & 46,3 \\
\hline Eğitim & & & \multicolumn{3}{|c|}{ Ne tür fiziksel aktivite yaparsınız? } \\
\hline Lise $\geq$ & 66 & 17,3 & Yürüyüş & 69 & 18,1 \\
\hline Ön lisans & 68 & 17,8 & Koşu & 24 & 6,3 \\
\hline Lisans & 180 & 47,1 & Fitness & 48 & 12,6 \\
\hline Lisansüstü & 68 & 17,8 & Halı saha & 26 & 6,8 \\
\hline Sigara kullanıyor musunuz? & & & Yoga & 3 & 0,8 \\
\hline Evet & 179 & 46,9 & Egzersiz & 9 & 2,3 \\
\hline Hayır & 203 & 53,1 & Plates & 6 & 1,6 \\
\hline Günde kaç saat uyuyorsunuz? & & & Tenis & 3 & 0,8 \\
\hline $7 \geq$ & 178 & 46,6 & Bisiklet & 6 & 1,5 \\
\hline $8 \leq$ & 197 & 51,6 & Yüzme & 8 & 2,0 \\
\hline Belirtmeyen & 7 & 1,8 & Güreş-Kick boks- Boks & 3 & 0,8 \\
\hline Günde ne kadar su içersiniz? & & & Voleybol & 3 & 0,8 \\
\hline $1000 \mathrm{ml} \geq$ & 157 & 41,1 & Basketbol & 2 & 0,8 \\
\hline $1200 \mathrm{ml}-2000 \mathrm{ml}$ & 162 & 42,4 & Dans & 2 & 0,6 \\
\hline $2500 \mathrm{ml} \leq$ & 63 & 16,5 & Tirmanma & 1 & 0,3 \\
\hline \multicolumn{6}{|l|}{ Kronik hastalığınız var mı? } \\
\hline Evet & 41 & 10,8 & & & \\
\hline Hayır & 341 & 89,3 & & & \\
\hline
\end{tabular}

Tablo 2'de değişkenlere ait ortalamalar, standart sapmalar, korelasyon katsayıları ve Cronbach Alpha değerleri verilmiştir. Araştırma değişkenlerine ilişkin temel istatistiklere bakıldığında, sağlıklı yaşam farkındalığı alt boyutları arasında en yüksek ortalamayı değişim $(4,147 \pm 0,661)$ boyutunun ve en düşük ortalamayı ise, sosyalleşme $(3,327 \pm 0,937)$ boyutunun aldığ 1 dikkat çekmektedir. Genel anlamda, araştırmaya katılan bireylerin sağlıklı yaşam farkındalık düzeylerinin ortanın üzerinde olduğu söylenebilir.

Tablo 2. Araştırma Değişkenlerine Ait Ortalamalar, Standart Sapmalar, Korelasyon ve Cronbach Alpha Değerleri

\begin{tabular}{lcccccc}
\hline Değişkenler & $\overline{\mathrm{x}}$ & ss & 1 & 2 & 3 & 4 \\
\hline Değişim & 4,147 & 0,661 & $(0,719) 1$ & & & \\
Sosyalleşme & 3,327 & 0,937 & $0,339 * *$ & $(0,742) 1$ & & \\
Beslenme & 3,469 & 0,934 & $0,350 * *$ & $0,367 * *$ & $(0,620) 1$ & \\
Sorumluluk & 3,888 & 0,805 & $0,507 * *$ & $0,304 * *$ & $0,403 * *$ & $(0,829)$ \\
\hline
\end{tabular}


Beslenme ile sorumluluk arasinda anlamlı ve pozitif yönlü bir ilişki vardır $(\mathrm{r}=0,403$; $\mathrm{p}<, 01)$. Ayrıca beslenme ile sosyalleşme arasinda $\quad(\mathrm{r}=0,367) ; \mathrm{p}<, 01)$, beslenme ve değişim arasında $\quad(\mathrm{r}=0,350 ; \quad \mathrm{p}<, 01)$, sosyalleşme ve değişim arasında $(\mathrm{r}=0,339$; $\mathrm{p}<, 01)$ ve sosyalleşme ve sorumluluk arasinda $(\mathrm{r}=0,304 ; \mathrm{p}<, 01)$ anlamlı ve pozitif yönlü bir ilişki vardır. Alt boyutların Cronbach Alpha değerlerine bakıldığında ise, değişim boyutu 0,719 , sosyalleşme boyutu 0,742 , sorumluluk boyutu 0,829 ve beslenme boyutu 0,620 olarak bulunmuş ve tüm boyutların oldukça güvenilir olduğu görülmüştür.

Tablo 3. Çeşitli Değişkenler ile Sağlıklı Yaşam Farkındalığı Ölçeği Alt Boyutlarına Ait Puan Ortalamalarının Karşılaştırılması

\begin{tabular}{|c|c|c|c|c|c|c|c|c|c|}
\hline \multirow[t]{2}{*}{ Değişkenler } & \multirow[t]{2}{*}{$\mathrm{N}$} & \multicolumn{2}{|c|}{ Değişim } & \multicolumn{2}{|c|}{ Sosyalleşme } & \multicolumn{2}{|c|}{ Beslenme } & \multicolumn{2}{|c|}{ Sorumluluk } \\
\hline & & $\bar{X}$ & SS & $\overline{\mathrm{X}}$ & SS & $\overline{\mathrm{X}}$ & SS & $\overline{\mathrm{X}}$ & SS \\
\hline \multicolumn{10}{|l|}{ Cinsiyet } \\
\hline Kadın & 202 & 4,174 & 0,681 & 3,329 & 0,899 & 3,511 & 0,881 & 3,907 & 0,777 \\
\hline $\begin{array}{l}\text { Erkek } \\
\text { Test İstatistiği }\end{array}$ & 180 & $\begin{array}{l}4,117 \\
t=0,836 \\
p=0,404\end{array}$ & 0,638 & $\begin{array}{l}3,325 \\
t=0,044 \\
p=0,965\end{array}$ & 0,980 & $\begin{array}{l}3,422 \\
t=0,932 \\
p=0,352\end{array}$ & 0,991 & $\begin{array}{l}3,866 \\
t=0,495 \\
p=0,621\end{array}$ & 0,837 \\
\hline \multicolumn{10}{|l|}{ Yaş (Yil) } \\
\hline $21-23$ & 122 & 4,186 & 0,054 & 3,278 & 0,912 & 3,366 & 0,892 & 3,978 & 0,786 \\
\hline $24-26$ & 108 & 4,151 & 0,628 & 3,136 & 0,901 & 3,466 & 0,923 & 3,827 & 0,784 \\
\hline $27-29$ & 46 & 4,178 & 0,722 & 3,489 & 1,004 & 3,630 & 0,994 & 3,992 & 0,742 \\
\hline 30 ve üzeri & 106 & 4,084 & 0,732 & 3,507 & 0,941 & 3,522 & 0,966 & 3,801 & 0,866 \\
\hline Test İstatistiği & & $\begin{array}{l}F=0,494 \\
p=0,687\end{array}$ & & $\begin{array}{l}F=3,420 \\
\mathbf{p}=\mathbf{0 , 0 1 7}\end{array}$ & & $\begin{array}{l}F=1,064 \\
p=0,364\end{array}$ & & $\begin{array}{l}F=1,383 \\
p=0,248\end{array}$ & \\
\hline \multicolumn{10}{|l|}{ Gelir (TL) } \\
\hline 3000 TL ve alt 1 & 210 & 4,148 & 0,718 & 3,298 & 0,974 & 3,458 & 0,952 & 3,925 & 0,836 \\
\hline $\begin{array}{l}3001 \text { TL ve üzeri } \\
\text { Test İstatistiği }\end{array}$ & 70 & $\begin{array}{l}4,254 \\
t=-1,376 \\
p=0,170\end{array}$ & 0,490 & $\begin{array}{l}3,514 \\
t=-1,698 \\
p=0,092\end{array}$ & 0,900 & $\begin{array}{l}3,595 \\
t=-1,025 \\
p=0,308\end{array}$ & 0,969 & $\begin{array}{l}3,947 \\
t=-0,209 \\
p=0,835\end{array}$ & 0,745 \\
\hline \multicolumn{10}{|l|}{ Medeni Durum } \\
\hline Evli & 102 & 4,015 & 0,764 & 3,561 & 0,864 & 3,522 & 0,945 & 3,764 & 0,843 \\
\hline Evli Değil & 280 & 4,195 & 0,613 & 3,242 & 0,949 & 3,450 & 0,931 & 3,933 & 0,787 \\
\hline Test İstatistiği & & $\begin{array}{l}t=-2,369 \\
\mathbf{p}=\mathbf{0 , 0 1 8}\end{array}$ & & $\begin{array}{l}\mathrm{t}=3,108 \\
\mathbf{p}=\mathbf{0 , 0 0 2}\end{array}$ & & $\begin{array}{l}\mathrm{t}=0,674 \\
\mathrm{p}=0,501\end{array}$ & & $\begin{array}{l}\mathrm{t}=-1,816 \\
\mathrm{p}=0,070\end{array}$ & \\
\hline \multicolumn{10}{|l|}{ Eğitim Durumu } \\
\hline Lise ve alt 1 & 66 & 3,981 & 0,818 & 3,420 & 0,944 & 3,353 & 0,990 & 3,782 & 0,966 \\
\hline Ön Lisans & 68 & 4,288 & 0,654 & 3,551 & 0,970 & 3,475 & 0,977 & 4,122 & 0,748 \\
\hline Lisans & 180 & 4,164 & 0,631 & 3,258 & 0,964 & 3,494 & 0,925 & 3,874 & 0,805 \\
\hline Lisansüstü & 68 & 4,123 & 0,543 & 3,194 & 0,797 & 3,469 & 0,870 & 3,794 & 0,638 \\
\hline Test İstatistiği & & $\begin{array}{l}\mathrm{F}=2,507 \\
\mathrm{p}=0,059\end{array}$ & & $\begin{array}{l}\mathrm{F}=2,314 \\
\mathrm{p}=0,076\end{array}$ & & $\begin{array}{l}\mathrm{F}=0,422 \\
\mathrm{p}=0,737\end{array}$ & & $\begin{array}{l}F=2,659 \\
\mathbf{p}=\mathbf{0 , 0 4 8}\end{array}$ & \\
\hline \multicolumn{10}{|l|}{ Sigara } \\
\hline Evet & 179 & 4,170 & 0,684 & 3,229 & 1,000 & 3,365 & 0,976 & 3,838 & 0,064 \\
\hline Hayır & 203 & 4,127 & 0,641 & 3,413 & 0,871 & 3,561 & 0,888 & 3,932 & 0,052 \\
\hline Test İstatistiği & & $\begin{array}{l}\mathrm{t}=0,646 \\
\mathrm{p}=0,518\end{array}$ & & $\begin{array}{l}\mathrm{t}=-1,929 \\
\mathbf{p}=\mathbf{0 , 0 5 4}\end{array}$ & & $\begin{array}{l}t=-2,060 \\
\mathbf{p}=\mathbf{0 , 0 4 0}\end{array}$ & & $\begin{array}{l}\mathrm{t}=-1,147 \\
\mathrm{p}=0,252\end{array}$ & \\
\hline \multicolumn{10}{|l|}{ Kronik hastalık } \\
\hline Evet & 40 & 4,290 & 0,597 & 3,606 & 0,837 & 3,558 & 0,146 & 3,908 & 0,138 \\
\hline Hayır & 341 & 4,132 & 0,667 & 3,295 & 0,945 & 3,462 & 0,050 & 3,884 & 0,043 \\
\hline Test İstatistiği & & $\begin{array}{l}\mathrm{t}=1,557 \\
\mathrm{p}=0,126\end{array}$ & & $\begin{array}{l}\mathrm{t}=2,189 \\
\mathbf{p}=\mathbf{0 , 0 3 3}\end{array}$ & & $\begin{array}{l}t=0,620 \\
p=0,538\end{array}$ & & $\begin{array}{l}t=0,176 \\
p=0,861\end{array}$ & \\
\hline
\end{tabular}

Tablo 3'te Sağlıklı Yaşam Farkındalı̆̆ ölçeğinin alt boyutlarına ilişkin puanların cinsiyet, gelir, medeni durum, sigara kullanma ve kronik hastalık değişkenleri ile karşılaştırmak için t testi uygulanmıştır. Yaş ve eğitim değişkenleriyle anlamlı bir ilişki olup olmadığını incelemek için ise ANOVA uygulanmıştır. Elde edilen bulgulara göre; cinsiyet ve gelir gruplarında alt boyutlar arasında istatistiksel olarak anlamlı bir ilişki ( $>>0,05)$ bulunmamıştır. Fakat tüm boyutlara bakıldığında kadınların erkeklere göre daha yüksek puanlara sahip olduğu görülmektedir. Aynı şekilde 3000 TL ve üzeri gelire sahip olanların $3000 \mathrm{TL}$ ve altı gelire sahip olanlara göre daha yüksek 
puanlara sahip olduğu tespit edilmiştir. İstatistiksel olarak anlaml bir fark bulunmasa da bu durum kadınların ve 3000 TL ve üzeri gelire sahip olanların sağlıklı yaşam farkındalığ 1 düzeylerinin daha yüksek olduğunu göstermektedir.

Yaş grupları incelendiğinde; sosyalleşme boyutuyla istatistiksel olarak anlamlı bir ilişki $(\mathrm{F}=3,420 ; \quad \mathrm{p}<0,05)$ görülmektedir. Aradaki anlamlı farkın kaynağının 24-26 yaş grubunun 27-29 ve 30 yaş üzeri gruplara göre sosyalleşme boyutundan daha düşük bir puan almasından kaynaklı olduğu söylenebilir. Bu nedenle ilk grup hariç 24-26 yaş grubunun sosyal alanlarda sağlıkla ilgili konularda dikkatlerini daha iyi vermedikleri söylenebilir. Medeni duruma bakıldığında, grupların değişim ve sosyalleşme alt boyutlar1 ile istatistiksel olarak anlamlı bir ilişkisi $\quad(\mathrm{t}=-2,369, \quad \mathrm{t}=3,108 ; \quad \mathrm{p}<0,05)$ bulunmuştur. Evli olmayanların değişim boyutunda aldıkları puanlar yüksekken evli olanların ise sosyalleşme boyutunda aldıkları puanlar yüksektir. Dolayısıyla evli olmayanların bedenleri üzerindeki değişimi daha iyi fark ettikleri ve evli olanların ise sosyal alanlarda sağlıkla ilgili konulara dikkat ettikleri söylenebilir. Eğitim düzeylerine göre sağlıklı yaşam farkındalığı algilarına bakıldığında; sorumluluk boyutuna ilişkin gruplar arasında anlamlı bir farklılık tespit edilmiştir $(\mathrm{F}=2,659 ; \mathrm{p}<0,05)$. Aradaki anlamlı farkın, ön lisans eğitim düzeyine sahip olanların, lise ve alt düzey, lisans ve lisansüstü eğitim düzeyine sahip olan bireylerden daha yüksek ortalamaya sahip olmalarından kaynaklandığ görülmektedir. Katılımcıların sigara içme durumlarına göre bakıldığında, sigara içenler ve içmeyenler arasında beslenme boyutunda istatistiksel olarak anlamlı bir ilişki $(\mathrm{t}=-2,060 ; \mathrm{p}<0,05)$ görülmektedir. $\mathrm{Bu}$ noktada sigara içmeyenlerin beslenme şekillerinin sağlıkları üzerinde oluşturduğu etkiyi daha fazla fark ettikleri söylenebilir.

Kronik hastalığa bakıldığında ise gruplar arasında sosyalleşme boyutunda istatistiksel olarak anlamlı bir ilişki $(\mathrm{t}=2,189 ; \mathrm{p}<0,05)$ olduğu görülmektedir. Diğer boyutlarda istatistiksel olarak anlamlı bir ilişki bulunmasa da tüm alt boyutlar arasında; kronik hastalığı olanların kronik hastalığı olmayanlara göre daha yüksek puan aldıkları görülmektedir. Dolayısıyla kronik hastalığı olanların sağlıklı yaşam farkındalık düzeyleri daha yüksektir denilebilir.

Bireylerin sosyalleşme boyutuna ilişkin tutumlarının değişim, beslenme ve sorumluluk boyutlarına göre daha düşük bir düzeyde olduğu tespit edilmiştir. Bu durum, daha önce Özer ve Yılmaz ${ }^{18}$ tarafından aynı konu ile ilgili yapılan çalışmada da benzerlik göstermektedir. Sağlıklı yaşam farkındalığını en az etkileyen boyut sosyalleşme boyutudur. $\mathrm{Bu}$ boyuttan düşük puan alınması bireylerin sosyal ortamlarda sağlıklarına ilişkin konulara dikkat vermekte güçlük çektiklerini göstermektedir. Yapılan bazı çalışmalarda Y kuşağı bireylerin sosyal medya kullanım düzeyi yüksek ve sosyal medyayı diğer bireylere göre daha yetkin kullandıkları bulunmuştur. ${ }^{19-20}$ Fakat $\mathrm{Y}$ kuşağ1 bireylerin sosyal medya kullanım düzeyleri ve kullanım yetkinlikleri göz önünde bulundurulduğunda, kendi sağlıklarını ilgilendiren konulara daha az dikkat ettikleri söylenebilir.

Katılımcıların, değişim alt boyutuna ait puanlarına göre, yalnızca medeni durum değişkeninde bir farklılık gösterdiği tespit edilmiştir. Literatürde evli bireylerin evli olmayan bireylere göre ev işleri ve çocuk bakımı gibi işler açısından önceden tahmin etme ve kontrollü olma yeteneğinin azaldığı görülmüştür. $^{21}$ Buna göre, evli olmayan bireylerin sağlı̆̆ında meydana gelen bir değişimi, hastalık belirtilerini, fiziksel ve ruhsal etkileri evli bireylere göre daha kolay fark edebildiği söylenebilir. Araştırma katılımcılarının sosyalleşme alt boyutuna vermiş oldukları puanları; yaş, medeni durum, sigara içme durumu ve kronik hastalığın varlığı değişkenleri açısından anlamlı farklilıklar göstermektedir. Buna göre, yaşın artmasına bağlı olarak bireylerin sosyal medya ve TV'den sağlıkla ilgili programları, paylaşımları dikkate aldıkları, yakın çevrenin sağlıklarına ilişkin tavsiyelerini göz önünde bulundurdukları söylenebilir. Öz ve Uyar'ın bir çalışmasında 
sağllk hizmetinde tavsiye alma ile ilgili katılımcılara sordukları soruya verilen cevaplara göre en fazla faydalanılan bilgi kaynağının aile, akraba ve arkadaş olduğu sonucuna ulaşılmıştır. ${ }^{22}$ Avc1 ve Sönmez' in yaptığı bir çalışmada ise bireylerin yaşı arttıkça televizyondan sağlık programlarını izleme siklıklarının arttığı sonucuna ulaşılmıştır. ${ }^{23}$ Yine medeni duruma göre evli bireylerin evli olmayan bireylere göre sosyal yönden sağliklarına daha fazla dikkat ettikleri ve farkındalık düzeylerinin yüksek olduğu görülmüştür. Ayaz ve diğerlerinin yaptığı bir çalışmada benzer şekilde evli olan bireylerin sağlık sorumlulukları yüksek bulunmuştur. ${ }^{24}$ Sigara içmeyen bireyler, sigara içenlere göre sosyalleşme boyutunda daha yüksek bir ortalamaya sahiptirler. $\mathrm{Bu}$ durum sigara içmeyen bireylerin sağlıkları söz konusu olduğunda gerek sosyal medya ve TV gerekse sosyal çevreden farkındalık düzeylerini artırmaya yönelik açık bir görüşe sahip olduklarını gösterir niteliktedir. Literatürde sigara içen bireylerin sosyal çevre ile ilişkiler ve herhangi bir durumda sosyal çevreden destek alma durumlarından daha az yararlandıkları şeklinde benzer bir bulguya rastlanmıştır. ${ }^{25}$ Yine kronik hastalı̆̆1 olan bireylerin sosyalleşme boyutundan daha yüksek bir puana sahip oldukları tespit edilmiştir. Kronik hastalığ olan bireylerin, sağlıklarını ilgilendiren konularda sosyal çevreden gelen bildirimlere yönelik daha açık ve ilgili olmalarıyla açıklanabilir. Polat ve Kahraman'ın yaşlı ve çoğu kronik hasta olan bireylerin sağlıklı yaşam biçimi davranışlarını inceledikleri bir çalışmada benzer bir bulgu olarak bireylerin sağlık sorumluluğu ve kişilerarası destek ile ilgili puanları yüksek bulunmuştur. ${ }^{26}$

Katılımcilarin alt beslenme boyutuna vermiş oldukları puanların sigara içme durumuna göre anlamlı farklılık gösterdiği tespit edilmiştir. Buna göre, sigara içmeyen bireylerin sağlıklı yaşam farkındalığının daha yüksek olduğu söylenebilir. Can'ın üniversite öğrencileri üzerinde yaptı̆̆ 1 benzer bir çalışmada sigara içmeyen bireylerin beslenme boyutuna ait puanları daha yüksek bulunmuştur. ${ }^{27}$ Son olarak; sorumluluk alt boyutuna verilen puanlar incelendiğinde, eğitim durumuna göre anlamlı bir farklılık olduğu görülmektedir. Ön lisans eğitim düzeyine sahip olan bireylerin sağlığa ilişkin sorumluluk algısının daha yüksek olduğu söylenebilir. Dikkat çekici bir husus da lisans düzeyine sahip bireylerin de farkındalık düzeylerinin lise ve altı ve lisansüstü eğitim düzeyinden daha yüksek puana sahip olmalarıdır. Arada anlamlı farklılık olmamasına karşın, sosyalleşme alt boyutundan lise ve alt düzey eğitim grubunun daha düşük puan aldığ 1 görülmüştür, bu durumun bireylerin sosyal medya ve TV, özellikle sosyal çevreden gelen sağlıkla ilgili paylaşım, bilgi ve tavsiyelerin yeterince değerlendirilememesinden kaynaklı olduğu düşünülmektedir. Literatürde benzer olarak hastane ve hekim seçiminde sosyal medya kullanım düzeylerinin incelendiği bir çalışmada lise eğitimi almış grubun daha düşük puanlara sahip olduğu görülmüştür. ${ }^{28}$

\section{SONUÇ VE ÖNERILER}

Bireylerin sağlıklarının korunması ve geliştirilmesi konusunda belirli bir düzeyde farkındalığa sahip olmaları çok sayıda değişkene bağlıdır. Bireyin bu değişkenler tarafindan şekillenen yaşamı, kendi sağlığına ilişkin farkındalık düzeyinin yüksek olmasıyla daha iyi bir seviyeye gelecek ve böylece birey bilinçli olarak iyilik halinin korunması ve geliştirilmesi hususunda çaba içerisinde olacaktır. Ayrıca sağlığı açısından zararlı davranışlardan uzaklaşması ve faydalı davranışlar arayışında olması ortaya çıkabilecektir. Bu çalışma Y kuşağı bireylerinin sağlıklı yaşam farkındalık düzeylerini belirlemek ve sosyodemografik özelliklerin sağlıklı yaşam farkındalığı üzerinde etkili olup olmadığının incelenmesini amaçlamaktadır. Çalışma sonucuna göre, bireylerin sağlıklı yaşama dair farkındalık düzeylerinin orta düzeyin üzerinde olduğu belirlenmiştir. 
Z kuşağı öncesi grupta yer alan Y kuşağı bireylerin, sağlıklı yaşama yönelik farkındalık düzeylerinin, tutum ve davranışlarının hem birey hem de toplum boyutuyla önem arz ettiği düşünülmektedir. $\mathrm{Bu}$ grubun önemi genç yetişkinleri kapsamas1, Türkiye nüfusunda büyük bir paya sahip olması, işgücünün büyük bir bölümünü oluşturması ve yaşlanacak yeni nesil olmasıyla ortaya çıkmaktadır. $\mathrm{Bu}$ gurubun sağlık sermayesi yönetiminde ve kendi sağlıklarına ilişkin hangi konularda farkındalık sahibi olduklarının bilinmesi; sağlık politika ve planlaması açısından önemlidir. $\mathrm{Bu}$ sebeple, yalnızca $\mathrm{Y}$ kuşağı kesimlerinde yer alan ve farklı özelliklere sahip tüm kesimlerin sağlıklı yaşam farkındalığının tespit edilmesi gerekli görülmektedir. $\mathrm{Bu}$ araştırma, Isparta'da ikamet eden Y kuşağı bireyleri ile sınırlı tutulmuştur. Ulusal boyutta tüm Y kuşağ1 bireylere genellenebilmesi açısından kisitlilik arz etmektedir. Gelecek araştırmalar sağlık çalışanları başta olmak üzere sağlık sektöründe gerçekleștirilebilir. Farklı örneklem grupları üzerinde özellikle sağlıklı yaşam farkındalığı ölçeğine ek olarak farklı değișken ve ölçeklerin dahil edildiği çalışmalar üzerinde durulabilir.

KAYNAKLAR

1. McCrindle, M. and Wolfinger, E. (2010). "Generations Defined". Ethos, 18 (1), 8-13.

2. Mannheim, K. (1952). "Essays on the Sociology of Knowledge". Oxford: Oxford University Press.

3. Zemke, R. Raines, C. and Filipczak, B. (1999). "Generations at Work: Managing the Clash of Veterans, Boomers, Xers and Nexters in your Workplace". New York: American Management Association.

4. Lower, J. (2008). "Brace Yourself Here Comes Generation Y". Critical Care Nurse, 28 (5), 80-84.

5. Zhang, K. and Bonk, C.J. (2010). "Generational Learners ve E-learning Technologies". Handbook of Research on Practices and Outcomes in E-learning. USA: IGI-Global.

6. Kampf, R. Lorincova, S. Hitka, M. and Stopka, O. (2017). "Generational Differences in the Perception of Corporate Culture in European Transport Enterprises". Sustainability, 9, 1-14.

7. Jain, V. and Pant S. (2012). "Navigating Generation $Y$ For Effective Mobile Marketing In India: A Conceptual Framework". Mobile Marketing Association IJMM Winter, 7 (3), 56-65.

8. Twenge, J.M. (2010). "A Review of the Empirical Evidence on Generational Differences in Work Attitudes". Journal of Business Psychology, 25, 201210

9. Berkup, S.B. (2015). "Sosyal Ağlarda Bireysel Mahremiyet Paylaşımı: X ve Y Kuşakları Arasında Karssılaștırmalı Bir Analiz" (Doktora Tezi). Ege Üniversitesi Sosyal Bilimler Enstitüsü, İzmir.

10. Behrstock-Sherratt, E. and Coggshall, J. (2010). "Realizing the Promise of Generation Y". Educational Leadership, 67 (8), 28-34

11. Buckley, R.M. Beu, D. S. Novicevic, M. M. and Sigerstad, T. (2001). "Managing Generation Next: Individual and Organizational Perspectives". Review of Business, 22 (1), 81-85.

12. Lovely, S. and Buffum, A. (2007). "Generations at School: Building an Agefriendly Learning Community". California: Corwin Press.
13. Göktaş, P. ve Çarıkçı, İ.H. (2015). "Kuşakların Siyasal İletişim Kültür ve Liderlik Açısından Değerlendirilmesi”. Mehmet Akif Ersoy Üniversitesi İktisadi ve İdari Bilimler Fakültesi Dergisi, 2 (1), 7-33.

14. T.C. Sağlık Bakanlığı. (2020). "Yeterli ve Dengeli Beslenme". Erişim adresi: https://hsgm.saglik.gov.tr/tr/ beslenme/yeterli-ve-dengeli-beslenme.html. (Erişim Tarihi: 02.24.2020)

15. Özkan, Ş. ve Aca, Z. (2020). "Akılcı İlaç Kullanımında Sağlıklı Yaşam Becerilerinin Etkisi”. Sosyal Güvenlik Dergisi, 10 (2), 273-288.

16. Dökmen, Ü. (2000). "Farkına Varmak" Yarına Kim Kalacak Evrenle Uyumlaşma Sürecinde Varolmak Gelişmek Uzlaşmak. İstanbul: Sistem Yayıncılık.

17. Rohrer, J. (2002). "Abc of Awareness. Personal Development as The Meaning of Life". Oberurnen: Utd Media Book Series.

18. Özer, E. ve Yılmaz, N. (2020). "Sağlıklı Yaşam Farkındalığı: Bir Ölçek Geliştirme Çalışması". Geleneksel ve Tamamlayıcı Tıp Dergisi, 3 (1), 47-60.

19. Fietkiewicz, K. J. Baran, K. S. and Stock, W. G. (2016) "Other Times, Other Manners: How Do Different Generations Use Social Media?". ARTS. Humanities Social Sciences\&Education January 8-11/Hawaii.

20. Ünal, A.T. ve Deniz, L. (2020). "Sosyal Medya Kuşaklarının Sosyal Medya Kullanım Seviyeleri ve Tercihleri”. Uluslararası Toplum Araştırmaları Dergisi, 15 (22), 1291-1319.

21. Ross, C.E. (1991). "Marriage and the Sense of Control". Journal of Marriage and Family, 53, 831-838.

22. Öz, M. Uyar, E. (2014). Sağllk Hizmetleri Pazarlamasında Algılanan Hizmet Kalitesi ve Müșteri Memnuniyeti Üzerinde Ağızdan Ağıza Pazarlamanın Etkisini Belirlemeye Yönelik Bir Araștırma”. KMÜ Sosyal ve Ekonomik Araştırmalar Dergisi, 16 (26), 123-132.

23. Bozkurt Avcı, İ. ve Sönmez, M.F. (2013). "Sağlık İletişimi Bağlamında Bireylerin Televizyonda Yayınlanan Sağlık Programlarını İzleme Alışkanlıkları ve Motivasyonları: Elazı̆̆ Örneği”. Gümüşhane Üniversitesi İletişim Fakültesi Elektronik Dergisi, 2 (2), 120-138. 
24. Ayaz, S. Tezcan, S. ve Akıncı, F. (2005). "Hemşirelik Yüksekokulu Öğrencilerinin Sağlığı Geliştirmeleri”. C.Ü. Hemşirelik Yüksek Okulu Dergisi, 9 (2), 26-34.

25. Acar, S. Şaşman Kaylı, D. ve Yararbaş, G. (2019). Sigara Kullanan, "Sigara Brrakma Tedavisi Alan ve Sigara Kullanmayan Bireylerin Psikolojik Dayanıklılık ve Stresle Başa Çıkma Tutumları Bakımından Karşılaştırılması". Addicta: The Turkish Journal on Addictions, 6, 539-566.

26. Polat, Ü. ve Bayrak Kahraman, B. (2013). "Yaşlı Bireylerin Sağlıklı Yaşam Biçimi Davranışları ve Algılanan Sosyal Destek Arasındaki İlişki”. Firat Tıp Dergisi, 18 (4), 213-218.

27. Can, M. (2021). "Üniversite Öğrencilerinde Sağlıklı Yaşam Biçimi Davranışlarının Sigara Kullanımına Etkisi” (Yüksek Lisans Tezi). İnönü Üniversitesi Sağlık Bilimleri Enstitüsü, Malatya.

28. Tengilimoğlu, E. Parıltı, N. ve Yar, C.E. (2015). "Hastane ve Hekim Seciminde Sosyal Medyanın Kullanım Düzeyi: Ankara İli Örneği”. İktisadi ve İdari Bilimler Fakültesi Dergisi, 17 (2), 76-96. 